\title{
Hispanic Women Owners In International Business Consulting: Where Are They?
}

Carmen M. Castro, New York Institute of Technology, Abu Dhabi Campus, UAE

\begin{abstract}
This academic research study addresses some of the social and economic business barriers being faced by Hispanic Business Owners in the field of International Business Management Consulting for multinational corporations MNCs. This research is very significant to the scholarly body of literature because it also highlights the struggles of Hispanic women when it comes to social recognition, political recognition, economic independence, cultural identity, traditional cultural and family values, educational achievement, and entrepreneurial business advancement. However, perhaps the most significant aspect of this research study is the development of the first characteristic model of successful Hispanic Women Business Owners.
\end{abstract}

\section{INTRODUCTION TO THE STUDY}

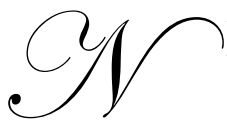

umerous research studies have been conducted internationally on patriarchal views in senior business management toward women. Empirical research has concluded that women have been discriminated against in patriarchal societies because of expectations related to gender and race, traditional cultural family values, and machismo among their male counterparts. Social stereotyping within corporate cultures steeped in masculine values often leads to a lack of promotional opportunities for women in senior management (Catalyst, 1999; Harris, 2002; Linehan, 2000; Wilen, 2000).

Hispanic women have been underrepresented in the academic literature on senior management positions in the international business field. In Catalyst's research and in other academic studies, less than $1 \%$ of those interviewed by Catalyst's were Hispanic women conducting international assignments (Catalyst, 2000). In most case studies, Hispanic women have been nonexistent because of the lack of interest among academic researchers in exploring the corporate lives of Hispanic women in international business management (Castro, 2003). Most studies on women in international business management have focused on White women and not on minority women. This is due in part to the fact that the international business field is very male oriented and dominated by White males. These factors have created "glass borders" for women that prevent them from obtaining senior management positions in multinational corporations (MNCs; Castro, 2003; Linehan, 2000).

This study investigated why there is so little interest in Hispanic women in senior international business management consulting and whether Hispanic women are being discriminated against more than their White female counterparts when seeking the same senior managerial positions (Castro, 2003). This study also investigated whether traditional cultural and family values prevent Hispanic women from reaching senior management status (Hofstede, 1984, 1997, 1998).

\section{THE PROBLEM}

The academic literature worldwide indicates that women seeking senior promotions and Hispanic women business owners of international business consulting firms face the following barriers: the need to balance work and family, isolation and loneliness, the feeling of being a woman in a man's world, the need to prove oneself constantly, the need to work harder and better than men, lack of business mentors, sexual harassment, cultural stereotyping, sexual discrimination, and low self-efficacy and business confidence (Adler, 1984; Catalyst, 1999; Harris, 2002; Linehan, 2000). The academic literature also argues that as long as the model for career development is male-oriented and does not allow time for child-raising, women will be at a disadvantage (Linehan, 2000). The 
academic literature has uncovered the problems of the "trailing spouse" and commuter marriage as great obstacles for Hispanic women business-owners in international business consulting firms seeking international business assignments aboard (Linehan, 2000).

Unfortunately, when academic studies are conducted on women in international business management, they tend to focus almost exclusively on White American and European businesswomen, leaving a gap in the research literature on the issues faced by Hispanic women in senior management. This gap in the research literature forms the basis of this academic research paper which seeks to address the social issues and business barriers faced by Hispanic women in the international business management field (Castro, 2003; 2006; 2007).

Minority women in the United States of America are viewed as "people of color." Disparate groups including Hispanic, African American, and Asian women have been categorized under this label when studies have been conducted on so-called minority women in international business management (Catalyst, 1999). Catalyst and other researchers have made the mistake of grouping data under one overly broad label of "women of color," which limits our understanding by concealing which minority group is actually facing the most significant social and business barriers to senior management positions in the field of international business management (Castro, 2003; 2006; 2007). Furthermore, this type of research misrepresents Hispanic women when it comes to their overall academic, social, and business management status and makes them virtually nonexistent in the academic literature (Castro, 2003; 2006; 2007). By being categorized as "women of color," minority women lose their cultural heritage and personal identity, which further limits our understanding of the cultural advancement of each of the ethnic groups subsumed under this broad term (Hofstede, 1984, 1997, 2005). As such, and in accordance with Hofstede's studies on culture, minority women should be grouped by their cultural background and not categorized under the unclear label of "women of color" (1984). In this spirit, the current study focuses on one particular group of women to understand their experiences and obstacles.

\section{LITERATURE REVIEW}

Academic research on women in international senior management positions has been fragmented since the mid-1980s. One of the most influential bodies of work in this discipline came from Dr. Nancy Adler (1984a, 1984b, 1984c, 1986, 1987). Adler conducted a series of studies to investigate the participation rate of women accepting international assignments overseas, and she also wanted to explore and identify the main obstacles that women faced when accepting international overseas assignments (Harris, 2002; Linehan, 2000; Soto, 1999). In particular, Adler attempted to explain the scarcity of females accepting international assignments by testing the veracity of three major "beliefs" that had emerged from the academic literature and the corporate sector (Harris, 2002):

1. Women do not want to be international managers.

2. $\quad$ Companies refuse to send women abroad.

3. Foreigners' prejudice against women renders them ineffective, even when they are interested in international assignments and are successful in being sent.

Adler (1984b) addressed the first myth in her research study by taking a survey of 1,129 graduating MBA students in Canada, the United States, and Europe. Her findings showed that graduate female students were very much interested in becoming international managers, as much so as their male counterparts (Harris, 2002; Linehan, 2000; Soto, 1999). Regarding the second myth, Adler's research uncovered that, in fact, companies did not refuse to send women abroad on international business assignments (Adler, 1984; Harris, 2002; Linehan, 2000; Soto, 1999).

However, the research did find problems associated with sending a woman abroad on an international business assignment when she is a part of a dual-career couple (Adler, 1984a; Harris, 2002; Linehan, 2000; Soto, 1999). Finally, Adler's findings in relation to the third myth revealed that female expatriates were seen as foreigners who happened to be women and were not therefore subjected to the same gender constructions and social constraints as local women from the host country of the assignment (Adler, 1984a; Harris, 2002; Linehan, 2000; Soto, 1999).

However, in her 1994 academic textbook Competitive Frontiers: Women Managers in a Global Economy, Adler noted that "minority women managers are not as well represented in the managerial ranks as their Anglo- 
Saxon women counterparts" (p. 393). In addition to their underrepresentation in the management ranks, Hispanic women managers earn lower wages than their White counterparts (Adler, p. 393). Adler also stated that Hispanic women in the United States get paid less than their African American counterparts when it comes to managerial jobs. Furthermore, for every dollar earned by men, women earn only 80 cents (Farrell, 2005). What this means is that Hispanic women are making even less than the 80 cents out of every dollar earned by their White female counterparts. Adler concluded in her study that "educationally, minority women are also lagging behind white women" and that business degrees were only being obtained at the bachelors, masters, and doctoral levels by White women in the United States (p. 393).

The main problem of Adler's study is that she failed to interview "minority women" herself. Instead, the data for her study came from a 1990 survey by UCLA's Anderson Graduate School of Management and Korn/Ferry International. Here is one manifestation of the problem: One of the endnotes in Adler's textbook states that "with the exception of table 23.6, statistics and references to minorities make no distinction between Blacks in general and Blacks who are of Hispanic origin or Whites in general and Whites who are of Hispanic origin" (Adler, 1994, p. 401). Since Hispanics could be either White or Black in the study upon which she based her conclusions, some of the statistics may have inaccurately reported racial and ethnic data.

Finally, the literature review suggested that there is no supporting evidence that women fail as expatriate senior managers (Copeland \& Griggs, 1985; Mendehall \& Oddou, 1985; Stone, 1991; Torbiorn, 1982; Tung, 1981). The literature review also pointed out actual evidence that women are able to complete their international assignments at a higher rate than their male counterparts (Adler, 1987; Caligiuri \& Tung, 1998; Taylor \& Napier, 1996). The other findings were that women do face gender discrimination, racial discrimination, barriers in raising children and holding down senior management positions, social stereotyping, and lack of international business assignments and senior promotions (Harris, 2002; Linehan, 2000; Soto, 1999).

\section{THE PURPOSE OF THE STUDY}

The purpose of this study was to identify the social barriers faced by Hispanic Women Business Owners in the international business management field and other female executives in senior management who are seeking senior promotions and international business assignments in the field of international business management. This academic study used qualitative research methods by distributing a survey, conducting in-depth interviews, and developing a questionnaire matrix in order to research the social barriers faced by Hispanic women in the international business field.

This research study also examined the educational backgrounds of Hispanic women and their career accomplishments in order to develop an overall characteristic model of the successful Hispanic women senior executives in the field of international business management (Castro, 2003; 2006; 2007). The study also considered the effects of traditional family/cultural values and the self-confidence of Hispanic women seeking senior promotions and international business assignments. This study also examined whether Hispanic women have to create their own MNCs in order to promote themselves into senior management positions and better place themselves for a competitive advantage in the international business arena (Castro, 2003; 2006; 2007). The final goal of this academic research study was to create the first characteristic model of successful Hispanic women in international business consulting and senior management in order to document their points of view and business contributions to the field of international business management (Castro, 2003; 2006; 2007).

\section{THE RESEARCH QUESTIONS}

1. How important is having a mentor to Hispanic women seeking to become female business owners and seeking international business assignments and senior promotions?

2. Do Hispanic women have to create their own corporations in order to promote themselves to senior management?

3. Are traditional cultural values influencing Hispanic Women Business Owners when they look for international business assignments and senior promotions in multinational corporations? 


\section{LIMITATIONS}

Among the limitations of this research study is the fact that only Puerto Rican, Chilean, Cuban and Argentinean women were interviewed. There were also time limitations and constraints of international schedules for these women business owners and female executives, who came from different parts of the world to San Juan, Puerto Rico to take part in this research study. There was also a limitation in the sample size of this study because of respondents' time constraints. The use of a questionnaire may have limited the overall objectivity of the study itself. Finally, selection bias may have affected this research study. The assumption was that by selecting only Puerto Rican, Chilean, Cuban and Argentinean women business owners and female executives, it would create variables of interest for that population of Hispanic women executives and not for the rest of the Hispanic population of women worldwide. This may or may not have been true; any errors of judgment in selection would have tended to counterbalance responses to the questionnaire (Castro, 2003; 2006; 2007).

\section{PARTICIPATORY RESEARCH}

As qualitative data are difficult to measure, count, or express in numerical terms, qualitative research typically uses observation, interviewing, and document review to collect data (Merriam-Webster's Collegiate Dictionary, 2005). Participatory research is the best methodology to achieve the goal of gathering qualitative data when conducting studies on cultural issues affecting executive women and on the effective business strategies women executives' use when conducting business in a host country. The participatory research methodology was developed by Charles Kieffer (1981) when he was conducting a study titled "Doing Dialogic Retrospection: Approaching Empowerment Through Participatory Research" in the field of anthropology. Other researchers have followed Kieffer's participatory research methodology, including Alma Ada and Constance Beutel in "Participatory Research as a Dialogue for Social Action" (1993); Susan Smith, Dennis Willms, and Nancy Johnson in "Nurtured by Knowledge: Learning to Do Participatory Action-Research" (1997); Robin McTaggart in "Participatory Action Research" (1997); William Foote Whyte in "Participatory Action Research" (1991); Bud Hall (1981); and Paulo Freire (1982). In addition, Wilen and Brannen (1993) used a participatory research methodology when writing their academic textbook Doing Business With Japanese: A Woman's Handbook (2000); Tracy Wilen used a participatory research methodology when conducting research for her doctoral dissertation, Women Doing Business in Mexico; and Margaret Linehan (2000) used a participatory research methodology when conducting research for her doctoral dissertation called Senior Female International Business Managers: Why So Few?

\section{IMPORTANCE OF THE STUDY}

This research study fills a gap in the international business management literature by focusing on the social and economic barriers faced by Hispanic women business owners and Hispanic women executives seeking international senior management positions in MNCs. This study is very significant to the scholarly body of literature on the topic because it also highlights the struggles faced by Hispanic women business owners when it comes to social recognition, political recognition, economic independence, cultural identity, traditional cultural and family values, educational achievement, and entrepreneurial business advancement. However, perhaps the most significant aspect of this research study is the development of the first characteristic model of successful Puerto Rican, Chilean, Cuban and Argentinean women business executives in senior international business management (Castro, 2003; 2006; 2007).

\section{BARRIERS TO HISPANIC WOMEN IN MANAGEMENT AND RESEARCH STUDIES AROUND THE WORLD}

The purpose of this study is to identify and understand the variables that might affect Hispanic women in obtaining international business assignments in a host country and to understand why there are so few Hispanic women in senior international business management. This study analyses the issues affecting Hispanic women business owners and minority women in senior corporate advancement in MNCs. The variables are gender discrimination, racial discrimination, cultural/family values, social acceptance, social desirability, social stereotyping, personal and cultural identity, self-efficacy, and self-confidence in obtaining senior international management positions and international business assignments (Castro, 2003; 2006; 2007). 


\title{
METHODOLOGICAL ISSUES IN THE STUDY OF CULTURE
}

\author{
In studying "values," we compare individuals; in studying "culture," we compare societies (Hofstede, 1984, \\ p. 23). As Hofstede observed,
}

When we base our study of culture on quantified data which have to be statistically treated, we meet a problem which the study of values of individuals did not present: the simultaneous analysis of data at the individual and at the societal level (p. 23).

What this means is that when Catalyst and other researchers fold together these three distinct minority groups into one group for the purpose of collecting data, their studies lose their cultural richness, the cultural values of each society, and the personal values of the individuals interviewed for the study (Castro, 2003; 2006; 2007).

For data collected at the societal level, we obviously have only a between-society correlation (Hofstede, 1984). In other words, minority women have been grouped together because of the color of their skin rather than by their cultural backgrounds. The other correlation that is associated with minority women is that they all have social and economic disadvantages and are viewed as underclass citizens by their White American counterparts (Castro, 2003; 2006; 2007). When minority women are grouped together only by the color of their skin in business literature, it becomes an "ecological correlation" which in turns transforms itself into an "ecological fallacy" (Hofstede, p. 24). "The problem of data from individuals within societies is that the various types of correlations referred to above most likely are not equal ... First, the within-society correlations may be significantly different from one society to the other society" (Hofstede, 1984, p. 24). Minority women from different ethnic groups do not share the same experiences when conducting international business assignments and do not function in the same business model or client engagement model because their individual cultures set them apart. Minority women are from different cultures, and research paradigms must recognize this by avoiding making correlations based on skin color (Castro, 2003; 2006; 2007).

\section{A COMPARISON OF HISPANIC WOMEN, AFRICAN AMERICAN WOMEN, AND ASIAN WOMEN}

Hispanic women are pioneers when it comes to international assignments, according to Catalyst's (2001) research on colored women executives. Hispanic and Asian women are taking more time to get married and start a family (Catalyst, 2001). Asian and Hispanic women are pursuing higher educational degrees in order to advance in their careers, but the numbers for Hispanic women are very low when it comes to masters and doctoral degrees (Catalyst, 2001). Hispanic and Asian women have a higher percentage of family-owned businesses than African American women do (Catalyst, 2001).

Hispanic and Asian women are always living and operating between two cultural worlds as they are forced to adjust to the American culture (Catalyst, 2001). However, Hispanic women continue to function well and are able to excel in the international business arena because they are bilingual, which gives them an added advantage when conducting international assignments (Catalyst, 2001). Hispanic women are the most international of these minority cultures because they are more willing to move internationally in order to advance their careers (Catalyst, 1999). Asian women are the least likely to have international careers; although they travel internationally to educate themselves, once their educational careers are completed, they tend to return to Asian countries (Catalyst, 2001). Asian American women are more Americanized and more competitive than their Asian counterparts in China and Japan (Catalyst, 2001). The same holds true for Hispanic American women; they, too, are more competitive than their counterparts in Latin American countries (Catalyst, 2001).

All three minority groups face huge problems when seeking cultural acceptance worldwide; they are often misunderstood when it comes to the struggle to achieve success and pursue higher education (Catalyst, 1999; Jones $\&$ Shorter-Gooden, 2003). Members of these three minority groups are frequently viewed as inferior by Whites, no matter how much they are able to achieve (Fox, 1996). Of the three minority groups, Hispanic women are the most discriminated against because of their bicultural lives and sense of cultural pride (Hofstede, 1984). There is also more discrimination against Hispanic women because they can have either "white" or "black" skin. This becomes an issue of social acceptance among the White majority (Hofstede, 1984). 
Minority women will always struggle for social advancement in American society as well as for international business appointments (Suarez-Orozco \& Páez, 2002). Things will only change when MNCs give women more opportunities to continue to advance in the field of international business management and when foreign cultures are able to gain more respect for women from around the world (Linehan, 2000). The human race will only advance when there are no more social barriers and no more color lines to define us as a Hispanic nation (Fox, 1996).

\section{THE FINDINGS OF THE NEW RESERACH STUDY}

The purpose of this study was to identify the social barriers faced by Hispanic women business owners and female executives in senior international business management seeking senior promotions and international business assignments. This study sought to amass supporting evidence through qualitative research methods and instruments including contact sheets, a questionnaire, and research questions, as well as in-depth interviews with executive women in senior international business management. This section discusses the findings of the research, which are based on participants' responses to the questionnaire and in-depth interviews. After describing the research process, the academic research moves into a description and analysis of the research findings (Castro, 2003; 2006; 2007).

\section{THE RESEARCH PROCESS}

The participatory research methodology used in this study involved the following research steps, as outlined by Kieffer (1981) and Wilen (2000):

1. Recruiting participants

2. Conducting structured dialogic interviews

3. Analyzing the data and searching for generative themes

4. Reflecting on the nature of the dialogues with the participants

5. Constructing meaning through integrative analysis

\section{DESCRIPTION OF STUDY PARTICIPANTS}

Using the participatory research methodology developed by Kieffer (1981) and used by Wilen for her doctoral dissertation (2000), participants interviewed for this academic research were Hispanic business owners in the field of international business management and international business consulting: 50 Hispanic Women Business Owners with International Business Consulting Firms in Puerto Rico, Argentina and Chile. The Hispanic women interviewed for this academic study worked in the international business management for 25-30 years and were between 39 and 55 years of age. Most of the Hispanic business owners only had a bachelor's degrees, only $3 \%$ had a master degree but they were able to advance into senior executive management positions because they created their own corporations in Puerto Rico, Chile and Argentina and only $1 \%$ of Hispanic women in Puerto Rico had earned a doctoral degree in international business management from the United States of America (Castro, 2003; 2006; 2007).

\section{THE INTERVIEWS}

Each interviewee participated in an e-mail conversation followed by a face-to-face, 60-minute interview in San Juan, Puerto Rico. All participants received and signed a confidentiality agreement. All meetings were conducted in a location chosen by the interviewee as amenable to an open but private discussion. A digital recorder was present at each meeting, and each interviewee was asked permission for the researcher to record the conversation in addition to taking notes by shorthand. The methodology required each participant to review their recorded interview and approve the session, as well as to reflect on their conversation, prior to leaving the interview (Keiffer, 1981; Wilen, 2000). As the interview process unfolded, the participants were asked to verify the accuracy and completeness of their statements, during which time gaps in the research questions and questionnaire were filled and new insights were shared (Wilen, 2000). No transcripts were given to the participants due to time and international travel constraints for the participants. 


\section{FINDINGS: RESEARCH QUESTIONS}

The findings of the study are organized below according to the research questions. The participants' answers are grouped according to the essential themes of the obstacles women face in obtaining international business assignments and senior promotions in the field of international business management. Each research question was developed with the literature review as a guide (Castro, 2003; 2006; 2007).

1. How important is having a mentor to Hispanic women seeking to become female business owners and seeking international business assignments and senior promotions? All 50 Hispanic women business owners agreed that it was important for all of them to have business mentors when they started their own international businesses in order for them to become international business consultants, Founders \& CEOs as well as to obtain international business assignments when they were in the early twenties and mid thirties.

2. Do Hispanic women have to create their own corporations in order to promote themselves to senior management? 30 Hispanic women business owners agreed that it was very important for them to start their own corporations in order for them to get senior management positions. Now, the other 20 Hispanic business owners stated that they had become business owners with the assistance of their male father who had already opened the door to the world of international business for them.

3. Are traditional cultural values influencing Hispanic Women Business Owners when they look for international business assignments and senior promotions in multinational corporations? All 50 Hispanic female business owners agreed that cultural influences and traditional family values affect the amount of time for their international business assignments aboard. Most of them all agreed that family values come first in most Hispanic cultures and that family plays a key role in the overall characteristics of the successful Hispanic Women Business Owner.

\section{SUMMARY}

This study found that Hispanic women business owners in international business management do want the assistance of a business mentor in order to become better international business consultants and future business Founders and CEOs. This study also found that there is a high incidence of racial and cultural stereotyping among Hispanic women when describing women from different Hispanic cultural groups. The findings also suggest that there is a lack of mentors among Hispanic women groups and within the field of international business management. There were no Hispanic women business role models for a woman business owner in international business consulting (Castro, 2003; 2006; 2007).

Finally, this study found that traditional family values play a key role in the decision-making practices of Hispanic women executives in international business management and that their husbands do support them in moving up into international senior management. What are holding other Hispanic women back from reaching senior management positions within the international business field are other Hispanic women executives who are threatened about the prospect of giving up their competitive advantage and knowledge base; they neither mentor nor help other Hispanic women executives reach their goals in achieving senior management. The discrimination comes from within their own community, and this competitiveness is keeping other Hispanic Women from reaching senior executive management and developing successful Hispanic international business networks and consulting firms with transitional leadership for future international growth (Castro, 2003; 2006; 2007).

\section{THERE INTERNATIONAL BUSINESS ASSIGNMENTS}

Most of these International Business Consultant Women Business Owners are conducting international assignments in the following international countries:

China, Beijing, Shanghai

The Middle East, Abu Dhabi, Dubai

Europe, London, Spain, Italy

South America, Argentina, Brazil, Chile

Africa, South Africa and Sudan 
Some to the advantages being faced by these Hispanic Women Business Owners is the ability of being able to live in multiple cultures and being able to speak more than just two languages besides English and Spanish. In fact, most of these Hispanic Business Owners master around four International languages making them more marketable than their White counter parts.

\section{CONCLUSIONS}

This research study found that Hispanic women business owners in international senior management were not discriminated against in their own countries for senior promotions or international business assignments, nor in a host country when they are conducting their overseas assignment instead it came from their own country's executive offices. This study also identified the importance of cultural values in the decision-making of Hispanic women in senior management. Traditional cultural values play a key role in the level of support shown by Hispanic women's spouses in for their senior management positions and international business contracts. They support their wives in their educational and career goals and keep the family together to honor their traditional family values (Castro, 2003; 2006; 2007).

This research study also found that Hispanic women business owners in senior international business management have very strong self-confidence and self-esteem when it comes to their career goals, the support of their spouses and family members, and the willpower to succeed in the field of international business management. To summarize, these women are highly educated, family-oriented, self-determined, highly competitive, selfconfident, highly entrepreneurial, and loyal to their companies, committed to their careers and families, and have a strong will to succeed (Castro, 2003; 2006; 2007).

\section{RECOMMENDATIONS}

The recommendations are for more quantitative research to be conducted in the study of other minority women in international senior management. This research study has provided new findings about Hispanic women business owners that need to be examined more, specifically the issues of cultural environment and competitiveness. The recommendations of this academic scholar are to examine if the same type of competitive cultural environment exists in the American, African American, Asian and European international business consulting firms (Castro, 2003; 2006; 2007).

\section{REFERENCES}

1. Ada, A. F., \& Beutel, C. M. (1993). Participatory research as a dialogue for social action. Participatory Research Journal, 29, 53-77.

2. Adler, N. (1984a). Expecting international success: Female managers overseas. Columbia Journal, 29, 5377.

3. Adler, N. (1984b). Women do not want international careers: And other myths about international management. International Journal of Intercultural Relations, 10(3), 277-300.

4. $\quad$ Adler, N. (1984c). Women in international management: Where are they? Management Review, 26(4), 7889.

5. Adler, N. (1986). Do MBAs want international careers? International Journal of Intercultural Relations, 10(3), 277-300.

6. Adler, N., \& Izraeli, D. (1994). Competitive frontiers: Women managers in a global economy. Cambridge, MA: Blackwell.

7. American Psychological Association. (2001). Publication manual of the American Psychological Association ( $5^{\text {th }}$ ed.). Washington, DC: Author.

8. Atkinson, P., Delamont, S., \& Hammersley, M. (1988). Qualitative research traditions: A British response to Jacob. Review of Educational Research, 58, 231-250.

9. Caligiuri, P. M., \& Cascio, W. (1998). Can we send her there? Maximizing the success of western women on global assignments. Journal of World Business, 33(4), 394-416. 
10. Caligiuri, P., \& Tung, R. (1998). Are masculine cultures female friendly? Male and female expatriates’ success in countries differing in work value orientations. Paper presented at the International Congress of the International Association for Cross-Cultural Psychology, Bellingham, WA.

11. Castro, C. (2003, December). Breaking through the glass ceiling: Women in management. Unpublished manuscript, Argosy University, Sarasota, FL.

12. Castro, C. (2007) Hispanic Women in Senior International Business Management: Why So Few? New York, Lincoln Shanghai: iUniverse Inc.,

13. Catalyst. (1999). Women of color in corporate management: Opportunities and barriers. New York: Author.

14. Catalyst. (2000). Passport to opportunity: U.S. women in global business: Executive summary. New York: Author.

15. Copeland, L., \& Griggs, L. (1985). Going international. New York: Random House.

16. Crabtree, B. F., \& Miller, W. L. (1994). Doing qualitative research: Multiple strategies. Newbury Park, CA: Sage.

17. Denzin, K. N., \& Lincoln, Y. (1994). The handbook of qualitative research. Thousand Oaks, CA: Sage.

18. Edgerton, R. T., \& Langness, L. L. (1974). Methods and styles in the study of culture. San Francisco: Chandler \& Sharp.

19. Farrell, W. (2005). Why men earn more: The startling truth behind the pay gap-And what women can do about it. New York: American Management Association (AMACOM).

20. Fox, G. (1996). Hispanic nation: Culture, politics, and the constructing of identity. Tucson: University of Arizona Press.

21. Fullerton, H. N., Jr. (1999, December). Labor force participation: 75 years of change, 1950-1998 and 1998-2025. Retrieved October 9, 2005, from http://stats.bls.gov/opub/mlr/ 1999/12/art/full.pdf

22. Gall, M. D., Borg, W. R., \& Gall, J. P. (1996). Educational research: An introduction (6 ${ }^{\text {th }}$ ed.). White Plains, NY: Longman.

23. Guilford, R. (1959). Personality. New York: McGraw-Hill.

24. Harris, H. (2002, April). Think international manager, think male: Why are women not selected for international assignment? Retrieved June 30, 2005, from http://r01.webmail.aol.com/ display-message.aspx

25. Hofstede, G. (1984). Culture's consequences: International differences in work related values. Newbury Park, CA: Sage.

26. Hofstede, G. (1998). Masculinity and femininity: The taboo dimension of national cultures. Thousand Oaks, CA: Sage.

27. Hofstede, G. (2005). Cultures and organizations: Software of the mind. New York: McGraw-Hill.

28. Jacob, E. (1987). Qualitative research traditions: A review. Review of Educational Research, 51, 1-50.

29. Jacob, E. (1988). Clarifying qualitative research: A focus on traditions. Educational Researcher, 17, $16-24$.

30. James, S. (2004, March). Adding value: The presentation of business information. Business Information Review, 21(1), 44-52.

31. Jones, C., \& Shorter-Gooden, K. (2003). Shifting: The double lives of Black women in America. New York: HarperCollins.

32. Kahn, R., \& Cannell, C. (1957). The dynamics of interviewing. New York: Wiley.

33. Kieffer, C. H. (1981, April 15). Doing dialogic retrospection: Approaching empowerment through participatory research. Paper presented at the International Meeting of the Society for Applied Anthropology, University of Edinburgh, Edinburgh, Scotland.

34. Linehan, M. (2000). Senior female international business managers: Why so few? London: Ashgate.

35. Locke, L. F., Spirduso, W. W., \& Silverman, S. J. (1993). Proposals that work: A guide for planning dissertations and grant proposals ( $3^{\text {rd }}$ ed.). Newbury Park, CA: Sage.

36. Marshall, C., \& Rossman, G. B. (1999). Designing qualitative research (3 ${ }^{\text {rd }}$ ed.). London: Sage.

37. McTaggart, R. (1997). Participatory action research: International context and consequences. Albany: State University of New York Press.

38. Mead, M. (1962b). National character. Chicago: University of Chicago Press.

39. Mendenhall, M., \& Oddou, G. (1985). The dimensions of expatriate acculturation: A review. Academy of Management Review, 10, 39-47.

40. Merriam-Webster's collegiate dictionary. (2005). Springfield, IL: Merriam-Webster.

41. Parsons, T. (1977). The evolution of societies. Englewood Cliffs, NJ: Prentice-Hall. 
42. Patton, M. Q. (1990). Qualitative research and evaluation methods ( $2^{\text {nd }}$ ed.). Newbury Park, CA: Sage.

43. Powell, G. N., \& Graves, L. M. (2003). Women and men in management (3 ${ }^{\text {rd }}$ ed.). Thousand Oaks, CA: Sage.

44. Pugel, T. A. (2004). International economics (12 ${ }^{\text {th }}$ ed.). New York: McGraw-Hill.

45. Rossman, G. B. (1984). I owe you one: Notes on role and reciprocity in a study of graduate education. Anthropology and Education Quarterly, 15, 225-234.

46. Selmer, J., \& Leung, A. (2000). Career intentions and adjustment of female business expatriates. Retrieved August 23, 2005, from http://net2.hkbu.edu.hk/-brc/CCMP200107.pdf

47. Smith, S., Willms, D., \& Johnson, N. (1997). Nurtured by knowledge: Learning to do participatory actionresearch. New York: Apex Press.

48. Soto, M. (1999). Puerto Rican women and international business opportunities. Paper presented at the International Conference on Women's Issues in International Business at the University of Puerto Rico.

49. Stone, R. (1991). Expatriate selection and failure. Human Resource Planning, 41(1), 9-18.

50. Strauss, A., \& Corbin, J. (1997). Grounded theory in practice. Thousand Oaks, CA: Sage.

51. Suarez-Orozco, M. M., \& Paez, M. M. (2002). Latinos: Remaking America. Los Angeles: Harvard University and University of California Press

52. Taylor, S., \& Napier, N. (1996). Working in Japan: Lessons from women expatriates. Sloan Management Review, 37(3), 76-84.

53. Torbiorn, I. (1982). Living abroad: Personal adjustment and personnel policy in the overseas setting. New York: Wiley.

54. Tung, R. (1981). Selection and training of personnel for overseas assignments. Columbia Journal, 23, 129143.

55. Whyte, W. F. (1991). Participatory action research. Newbury Park, CA: Sage.

56. Wilen, T. (2000). Women doing business in Mexico. Unpublished doctoral dissertation, Golden Gate University, San Francisco, CA.

57. Wilen, T., \& Brannen, C. (1993). Doing business with Japanese: A woman's handbook. Berkeley, CA: Stonebridge.

58. Wirth, L. (2001). Breaking through the glass ceiling: Women in management. Geneva: International Labour Office. 